\title{
Bioactive glass/hydroxyapatite composites: Mechanical properties and biological evaluation
}

\author{
Devis Bellucci $^{\text {a,* }}$, Antonella Sola ${ }^{\text {a }}$, Alexandre Anesi ${ }^{\text {b }}$, Roberta Salvatori ${ }^{\text {b }}$, Luigi Chiarini ${ }^{\text {b }}$, Valeria Cannillo ${ }^{\text {a }}$ \\ a Dipartimento di Ingegneria “E. Ferrari”, Università di Modena and Reggio Emilia, Via P Vivarelli 10, 41125 Modena, Italy \\ ${ }^{\mathrm{b}}$ Laboratorio dei Biomateriali, Dipartimento di Scienze Mediche Chirurgiche Materno-Infantili e dell'Adulto, Università di Modena e Reggio Emilia, Via Campi 213/A, 41125 Modena, Italy
}

\section{A R T I C L E I N F O}

Article history:

Received 3 October 2014

Received in revised form 21 January 2015

Accepted 24 February 2015

Available online 25 February 2015

\section{Keywords:}

Composites

Hydroxyapatite

Bioglass

Cytotoxicity

Cell culture

\begin{abstract}
A B S T R A C T
Bioactive glass/hydroxyapatite composites for bone tissue repair and regeneration have been produced and discussed. The use of a recently developed glass, namely BG_Ca/Mix, with its low tendency to crystallize, allowed one to sinter the samples at a relatively low temperature thus avoiding several adverse effects usually reported in the literature, such as extensive crystallization of the glassy phase, hydroxyapatite (HA) decomposition and reaction between $\mathrm{HA}$ and glass. The mechanical properties of the composites with $80 \mathrm{wt}$ \% BG_Ca/Mix and $20 \mathrm{wt} . \% \mathrm{HA}$ are sensibly higher than those of Bioglass ${ }^{\circledR} 45 \mathrm{~S} 5$ reference samples due to the presence of HA (mechanically stronger than the $45 \mathrm{~S} 5$ glass) and to the thermal behaviour of the BG_Ca/Mix, which is able to favour the sintering process of the composites. Biocompatibility tests, performed with murine fibroblasts BALB/3T3 and osteocites MLO-Y4 throughout a multi-parametrical approach, allow one to look with optimism to the produced composites, since both the samples themselves and their extracts do not induce negative effects in cell viability and do not cause inhibition in cell growth.
\end{abstract}

(c) 2015 Elsevier B.V. All rights reserved.

\section{Introduction}

One of the most interesting research areas of materials science deals with the development of bioceramics for bone reconstructive surgery, aiming to restore functions of damaged calcified tissues of the body. Examples comprise periodontal treatments and dental fillings as well as spinal surgery, cranio-maxillofacial reconstruction, joint replacement, fracture treatment and, in particular, healing of deteriorated bone or bone defects with bone-graft substitutes [1-3]. An ideal bonegraft substitute must be able to integrate with the remaining bone, thus providing structural stability with neo-ossification through osteoconduction and osteoinduction [4]. Moreover, the artificial substitute is gradually replaced by a new tissue with no transient loss of mechanical support. Among bioceramics, hydroxyapatite (HA) is the most similar material to the mineral component of bones; it exhibits biocompatibility, osteoconductivity and bioactive behaviour, being able to bond to the bone directly. For these reasons, HA has been employed in powder form or granules in many oral, maxillofacial and orthopaedic applications [5,6], and to realize bioactive coatings on metal implants in order to provide them with an osteophilic surface, which promotes a stronger bone-to-implant bonding [7,8]. Unfortunately, although HA is bioactive, its reactivity with existing bone tissue

\footnotetext{
* Corresponding author at: Dipartimento di Ingegneria "E. Ferrari”, Università di Modena and Reggio Emilia, Via Vignolese 905, 41125 Modena, Italy.

E-mail address: devis.bellucci@unimore.it (D. Bellucci).
}

is low. In fact, HA implants suffer minimal degradability in physiological environment and they cannot be resorbed or replaced by a newly formed bone [1]. For these reasons, the failure of HA-based implants may occur through the fracture of the HA-bone interface or the implant itself. One promising way to deal with these problems is to reinforce HA by adding a bioactive glassy phase in order to obtain a composite. Bioactive glasses, in fact, are characterized by a higher bioactivity index compared to HA, and specific compositions, such as the widely used 45S5 Bioglass ${ }^{\circledR}$, are able to bond to soft tissues as well as to hard ones [6]. It is reported that glass-reinforced HA shows greater biological activities with respect to commercial HA $[9,10]$. This occurs because silicatebased glasses release critical concentrations of ions (such as $\mathrm{Si}, \mathrm{P}$ or Ca) in vivo, which are able to stimulate bone formation and to play an important role both in angiogenesis and in neo-vascularization [11, 12]. The improvement in the mechanical properties of HA associated with addition of bioglass is also documented by several authors [13, 14]. Probably the main drawback of employing bioglasses in HA-based composites is the high temperature $\left(1200^{\circ} \mathrm{C} \div 1300^{\circ} \mathrm{C}\right)$ required to sinter these samples, which may cause several adverse effects such as reactions between HA and glass, with the formation of new undesired phases, the decomposition of HA itself $[15,16]$ and the crystallization of the glass, which is expected to decrease or even to inhibit the bioactivity of the final system [17-19]. In order to face these issues, new bioactive glasses with a high thermal stability are required. With this aim, a CaO-rich bioactive glass, named BG_Ca, was tested in previous works to produce HA-based composite materials with HA contents ranging from 50 wt.\% to 80 wt.\% $[20,21]$. The relatively high $\mathrm{CaO}-$ to- $\mathrm{Na}_{2} \mathrm{O}$ ratio in the 
BG_Ca composition (4.6 mol\% $\mathrm{Na}_{2} \mathrm{O}, 45.6 \mathrm{~mol} \% \mathrm{CaO}, 2.6 \mathrm{~mol} \% \mathrm{P}_{2} \mathrm{O}_{5}$, $47.2 \mathrm{~mol} \% \mathrm{SiO}_{2}$ ) was indeed responsible for a substantial reduction in the tendency to devitrify with respect to the "gold standard" 45S5 Bioglass ${ }^{\circledR}[22]$, thus facilitating the production of HA-based composites. Now, as a further improvement, the present contribution proposes to work with a potassium-modified formulation of the precedent BG_Ca, which is the new BG_Ca/Mix glass (2.3 mol\% $\mathrm{Na}_{2} \mathrm{O}$, $2.3 \mathrm{~mol} \% \mathrm{~K}_{2} \mathrm{O}, 45.6 \mathrm{~mol} \% \mathrm{CaO}, 2.6 \mathrm{~mol} \% \mathrm{P}_{2} \mathrm{O}_{5}$, and $47.2 \mathrm{~mol} \% \mathrm{SiO}_{2}$,) [23, $24]$. In fact, the presence of potassium oxide in the glass composition improves even more the thermal stability of the glass, thus increasing its crystallization onset temperature with respect to the starting BG_Ca and a fortiori with respect to $45 \mathrm{~S} 5$ Bioglass ${ }^{\circledR}$. As a matter of fact, the DTA performed on the BG_Ca/Mix powders revealed a glass transition temperature of about $720^{\circ} \mathrm{C}$ and a crystallization temperature of $880^{\circ} \mathrm{C}[23,24]$, while $45 \mathrm{~S} 5$ Bioglass ${ }^{\circledR}$ starts its crystallization at temperatures as low as $610^{\circ} \mathrm{C}[17-19]$. The presence of potassium in the glass is expected to exert a positive effect also in terms of biological response of the implant. The inorganic phases of hard tissues are mainly composed of calcium and phosphorous, but they also contain considerable amounts of sodium, magnesium, $\mathrm{CO}_{3}^{2-}$, fluorine and indeed potassium $[25,26]$. For this reason, in the past potassium has been extensively used both in glasses and glass-ceramics for biomedical applications [27-30]. The role of the aforementioned modifying elements and ions is even more relevant when bioactive glasses are mixed to synthetic HA in order to produce composites. In this case, several ionic substitutions may occur within the $\mathrm{HA}$ lattice, such as $\mathrm{F}^{-}$for $\mathrm{PO}_{4}^{3-}$ or $\mathrm{Na}^{+}$for $\mathrm{Ca}^{2+}$, thus giving rise to crystalline defects and microstresses which modify the original HA solubility, thus mimicking the behaviour of biological apatites, which are more reactive than synthetic ones. In the last decades, the use of phosphate and silicate glasses with the addition of $\mathrm{MgO}, \mathrm{CaF}_{2}, \mathrm{Na}_{2} \mathrm{O}$ and $\mathrm{K}_{2} \mathrm{O}$ has been widely exploited aiming to incorporate such ions within $\mathrm{HA}$, in order to develop innovative composites with composition similar to that of the mineral part of bone [31-33].

In a recent introductory contribution, the potassium modified BG_Ca/Mix glass was tested for the first time to fabricate bioceramic composites [34]. Binary mixtures of BG_Ca/Mix and HA or $\beta$ tricalcium phosphate have been sintered at a relatively low temperature ( $818^{\circ} \mathrm{C}$ or $830^{\circ} \mathrm{C}$ depending on the sample) thanks to the peculiarities of the glass. In this way it was possible to almost preserve the glassy phase in the samples, thus obtaining binary composites which looked rather promising in terms of in vitro bioactivity [34]. However, the biocompatibility of such BG_composites with respect to cells was not tested.

In the present contribution, the attention has been focused on BG_Ca/Mix-HA composites and a step forward in the achievement of such materials has been taken. First of all, the formulation of the composites has been modified in order to account for the feasibility and properties of both glass-rich composites and HA-rich ones. In this sense, a first set of glass-based samples has been obtained by increasing the content of glass to $80 \mathrm{wt} . \%$ in order to exploit its bioactivity and its sintering capability at best. At the same time, a second set of HA-based composites containing as low as 30 wt.\% BG_Ca/Mix has been discussed in order to investigate samples with a relatively low (but still sensible) amount of glass. Besides that, a substantial novelty of the present contribution is provided by in vitro tests performed on fibroblasts and osteocyte-like cells to determine the cytotoxicity of both types of composites.

$45 \mathrm{~S} 5$ Bioglass ${ }^{\circledR}$ powders have been also pressed and sintered in order to obtain reference samples as a term of comparison. The samples have been characterized from a mechanical point of view, using a depth-sensing micro-indentation technique to estimate the local elastic modulus and hardness. Moreover, the biocompatibility of new composites has been evaluated in vitro in cell culture, in comparison with $45 \mathrm{~S} 5$ Bioglass $®$, throughout a multi-parametrical approach.

\section{Materials and methods}

\subsection{Samples' preparation}

BG_Ca/Mix was prepared by melting the raw materials (commercial $\mathrm{SiO}_{2}, \mathrm{CaCO}_{3}, \mathrm{Ca}_{3}\left(\mathrm{PO}_{4}\right)_{2}, \mathrm{Na}_{2} \mathrm{CO}_{3}$ by Carlo Erba Reagenti, Italy) in a crucible at $1450{ }^{\circ} \mathrm{C}$ for $1 \mathrm{~h}$ in air. Then the melted glass was cast into cold water to obtain a frit. After a $24 \mathrm{~h}$ drying step in an oven at $110^{\circ} \mathrm{C}$, the frit was crushed in a porcelain ball mill for $1 \mathrm{~h}$ and sieved to a grain size below $45 \mu \mathrm{m}$.

The BG_Ca/Mix glass powders were mixed with HA powders (CAPTAL ${ }^{\circledR}$ Hydroxylapatite, Plasma Biotal Ltd, UK) for $8 \mathrm{~h}$ in a plastic bottle using a roll shaker in order to prepare composites with the following compositions:

- 80 wt.\% BG Ca/Mix and 20 wt.\% HA powders ("BGCaM80");

- 30 wt.\% BG_Ca/Mix and 70 wt.\% HA powders ("BGCaM30").

The mixed powders were pressed at $45 \mathrm{MPa}$ for $15 \mathrm{~s}$ using acetone as a liquid binder to obtain green bodies shaped in a disc form (12 $\mathrm{mm}$ of nominal diameter and $2 \mathrm{~mm}$ of thickness).

Several sintering tests were performed aiming to produce samples with the best compromise between adequate compactness and low crystallization of BG_Ca/Mix; in particular, the densification of the samples was monitored by measuring their volume shrinkage. The thermal treatment was set at a final temperature of $830{ }^{\circ} \mathrm{C}$ for BGCaM80 and $900{ }^{\circ} \mathrm{C}$ for BGCaM30, respectively. As previously mentioned, such temperatures led to a balance between densification and crystallization: lower temperatures were indeed associated to a partial compaction, with sensible residual porosity and poor mechanical properties (the samples could be broken by hand or easily scratched with a screwdriver), whereas higher temperatures caused a wide devitrification or even a sample deformation (overheating). It is interesting to note that the sintering temperature was lower for the BGCaM80 composite than for the BGCaM30 one, due to the higher content of glass which acts as a sintering aid. For both composite materials, the heating rate was set at $5{ }^{\circ} \mathrm{C} / \mathrm{min}$ up to $500{ }^{\circ} \mathrm{C}$ and subsequently at $10{ }^{\circ} \mathrm{C} / \mathrm{min}$ up to the sintering temperature. Both types of samples were heat-treated for $3 \mathrm{~h}$ at the maximum temperature and then extracted from the oven and left to cool to room temperature.

$45 \mathrm{~S} 5$ Bioglass ${ }^{\circledR}$ reference samples (“45S5”) were also produced starting from commercial 45S5 Bioglass ${ }^{\circledR}$ powders (MO-SCI Health Care LLC, Rolla, MO, USA), which were pressed at 45 MPa for $15 \mathrm{~s}$ using acetone as a liquid binder. In this case, green bodies were treated at $1050{ }^{\circ} \mathrm{C}$ for $3 \mathrm{~h}$, according to Ref. [35].

\subsection{Microstructural and mechanical characterization}

The polished cross-sections of the samples were observed with an environmental scanning electron microscope, ESEM (ESEM Quanta 200-FEI Company, Eindhoven, The Netherlands) coupled with an Energy-Dispersive X-ray (X-EDS) microanalysis system (INCA, Oxford Instruments, U.K.). The microscope was operated in a low-vacuum mode with a pressure of 0.5 Torr. The phase composition of the composites was determined by X-ray diffraction (XRD: X'Pert PRO; Panalytical, Almelo, the Netherlands). Data collection was performed by a $2 \theta$ scan method in the range of $10-70^{\circ}$ using $\mathrm{Cu}-\mathrm{k} \alpha \mathrm{X}$-ray line with a step size of $0.017^{\circ} 2 \theta$ and scan step time of $61.59 \mathrm{~s}$.

In order to investigate the local mechanical properties of the composites, depth-sensing Vickers micro-indentations (OpenPlatform, CSM Instruments, Peseux, Switzerland) were performed on the polished cross sections by applying a maximum load of $2 \mathrm{~N}$ for $15 \mathrm{~s}$, with a loading and unloading rate of $3 \mathrm{~N} / \mathrm{min}$. In particular, for each indentation, the penetration depth curve (i.e. depth vs applied load) was automatically recorded by the instrument and analysed according to the 
Oliver and Pharr method [36]. For each material, at least 10 indentations were considered to have an average value of the local elastic modulus and micro-hardness. The same procedure was applied to the pure $45 \mathrm{~S} 5$ sintered bodies, which represent a term of comparison.

\subsection{Assessment of in vitro bioactivity}

The apatite-forming ability of the BGCaM80 and BGCaM30 samples was investigated in vitro in a Simulated Body Fluid solution (SBF), i.e. an aqueous solution which mimics the (acellular and protein-free) human blood plasma [37]. The evaluation of the $45 \mathrm{~S} 5$ in vitro bioactivity has been previously reported elsewhere [35]. The samples were stored in closed plastic flasks containing SBF and kept at $37^{\circ} \mathrm{C}$ in a controlled environmental chamber (MPM Instruments S.r.l., Bernareggio, MI, Italy). The solution was refreshed every $48 \mathrm{~h}$. The samples were removed from SBF after time periods of 3, 7 and 14 days, washed with distilled water and dried at room temperature. The surface of the samples was observed in an ESEM and qualitative chemical analyses were obtained by means of X-EDS. The apatite precipitation on the samples' surface was further verified by means of micro-Raman spectroscopy (Jobin-Yvon Raman Microscope Spectrometer, HORIBA Jobin-Yvon S.A.S., Villeneuve d'Ascq, France), with a diode laser source having the power of $20 \mathrm{~mW}$ at the wavelength $632.8 \mathrm{~nm}$ ( $100 \times$ objective). A spectra collection of 15 acquisitions of $30 \mathrm{~s}$ each has been used.

\subsection{Biocompatibility tests}

BALB/3T3 (mouse embryonic fibroblast cell line) and MLO-Y4 (murine long bone osteocyte-like immortalized cell line) cells were employed in order to evaluate in vitro the biocompatibility of the produced samples (BGCaM80, BGCaM30 and 45S5 for comparison). The materials' cytotoxicity was tested both through direct contact, i.e. the cells are seeded directly onto the material and incubated in suitable conditions, and indirect contact, in order to evaluate the cytotoxic effects of the extracts of the samples obtained by treating them in a centrifuge tube containing DMEM (culture medium). Cell survival/ viability and proliferation were evaluated by means of Neutral Red (NR) uptake, tetrazolium salt XTT (2,3-bis(2-methoxy-4-nitro-5sulfophenyl)-5-[(phenylamino) carbonyl]-2H-tetrazolium hydroxide) and Bromodeoxyuridine (BrdU) assays.

\subsubsection{Culture of MLO-Y4 and BALB/3T3 cells}

BALB/3T3 and MLO-Y4 cells were cultured in Dulbecco's modified Eagle's medium (DMEM) (Invitrogen, Karlsruhe, Germany), supplemented with $10 \%$ foetal bovine serum (Invitrogen), $100 \mu \mathrm{g} / \mathrm{ml}$ penstreptomycin (Invitrogen), D-Glutamine $2 \mathrm{mM}$ and sodium pyruvate $1 \mathrm{mM}$ (Invitrogen) on 6 well plates for direct contact with the samples dishes and the Neutral Red (NR) assay procedure was performed (see next paragraphs). The cells were maintained in a $37{ }^{\circ} \mathrm{C}$ and $5 \% \mathrm{CO}_{2}$ humidified incubator and subcultured approximately every $72 \mathrm{~h}$ to maintain the cell populations at less than $70 \%$ confluent.

\subsubsection{Preparation of samples' extracts}

The extracts of the samples to be employed in indirect contact tests were obtained by treating the composites in centrifuge tubes, $6 \mathrm{~cm}^{2} / \mathrm{ml}$ area each containing DMEM. A vial with DMEM and $0.45 \%$ of phenol solution was used as positive control (CTRL + ) while a vial with $6 \mathrm{ml}$ of DMEM only was used as negative control (CTRL - ). According to ISO 10993-5 [38] vials were incubated at $37^{\circ} \mathrm{C}$ for 5 days and $\mathrm{pH}$ measures were carried out in order to verify the physiological conditions of the medium. Before cytotoxicity test, every extract was filtered by a $0.22 \mu \mathrm{m}$ filter [39].

\subsubsection{NR test}

The NR cytotoxicity (Neutral Red solution N6264 Sigma, Germany) assay procedure is a widely used cell survival/viability assay based on the ability of viable cells to incorporate and bind neutral red, a supravital dye. Healthy cells, in fact, continuously divide and multiply over time when properly maintained in culture, while a toxic chemical will interfere with this process, thus resulting in a decreasing of the growth rate and cell population. The degree of inhibition of growth is related to the concentration of the toxic xenobiotics and provides an indication of the cytotoxicity of the material. Cells (BALB/c 3T3 cells and MLOY4 cell) were cultured at $37{ }^{\circ} \mathrm{C} \pm 1{ }^{\circ} \mathrm{C}, 90 \% \pm 5 \%$ humidity, and $5.0 \% \pm 1 \%$ $\mathrm{CO}_{2} /$ air for $24 \mathrm{~h}$. The culture medium was removed and then $250 \mu \mathrm{L}$ of NR solution were added to all wells including the blanks. After incubation, the NR solution was removed and cells were carefully rinsed with $250 \mu \mathrm{L}$ D-PBS. Subsequently $100 \mu \mathrm{L}$ NR Desorb (ETOH/acetic acid) solution was added to all wells for 20 min to extract NR from the cells and to form a homogeneous solution. The test was repeated in triplicate for each sample used. The quantity of dye incorporated into cells was measured using spectrophotometry at $540 \mathrm{~nm}$ (Multiscan RC by Thermolab system, Finland) using two references, DMEM without serum as CTRL - and phenol $0.45 \%$ as CTRL +.

\subsubsection{Morphological evaluations}

The morphology of the cells after $24 \mathrm{~h}$ direct/indirect contact with the samples was evaluated using optical microscopy (Nikon TMF, Japan).

\subsubsection{XTT test}

XTT assay is a standard protocol which aims to evaluate the cell viability via cellular metabolic activity [40]. This test is based on the cleavage of the yellow tetrazolium salt XTT to form an orange formazan dye by mitochondrial enzymes in metabolic active cells. It is possible to directly quantify the formazan dye formed by means of spectrophotometry, as it is highly water-soluble [41,42]. Cells were grown in 96 well culture plates and then incubated with extracts of the samples for $24 \mathrm{~h}-48 \mathrm{~h}$. After incubation XTT labelling solution (Cell Proliferation Kit II (XTT) Roche diagnostics, USA) was added (final concentration $0.3 \mathrm{mg} / \mathrm{ml}$ ). After $4 \mathrm{~h}$, a colorimetric reaction due to the newly synthesized orange formazan dye solution was quantified measuring absorbance at wavelength of $490 \mathrm{~nm}$. An increase in number of living cells results in an increase in the overall activity of mitochondrial dehydrogenases in the sample and this fact directly correlates to the amount of the orange water-soluble product generated from XTT, as monitored by spectrophotometry. As references, DMEM without serum as CTRLand phenol $0.45 \%$ as CTRL + were employed.

\subsubsection{Bromodeoxyuridine (BrdU) test}

BrdU cell proliferation assay is a well-established and commonly used technique which aims to measure the incorporation of 5-bromo-2deoxyuridine in replicating DNA of proliferating cells, in order to evaluate cell proliferation. Cells grown in 96 well plates, after $24 \mathrm{~h}-48 \mathrm{~h}$ exposure to the samples' extracts, were then added with $50 \mu \mathrm{l} /$ well of BrdU labelling solution (Cell Proliferation ELISA, BrdU, Roche). During this incubation period, BrdU is incorporated in place of thymidine into the newly synthesized DNA of cycling cells. The labelling culture medium was then removed and FixDenat solution (Cell Proliferation ELISA, BrdU, Roche) was added in order to fix cells and to denature DNA in one step. Subsequently, this solution was removed and the samples were incubated with an antibody conjugated to peroxidase (anti-BrdU-POD), which binds to the BrdU incorporated into the newly synthesized cellular DNA. The immune complexes were then detected through the subsequent substrate reaction. The reaction product was evaluated by measuring the absorbance at a wavelength of $370 \mathrm{~nm}$. The intensity of the detected signal is directly correlated to the amount of the new DNA, and therefore to the number of proliferating cells in the culture.

\subsubsection{Statistical analyses}

All results were statistically treated using one-way variance analysis (ANOVA). All results are expressed as the mean \pm standard deviation. 

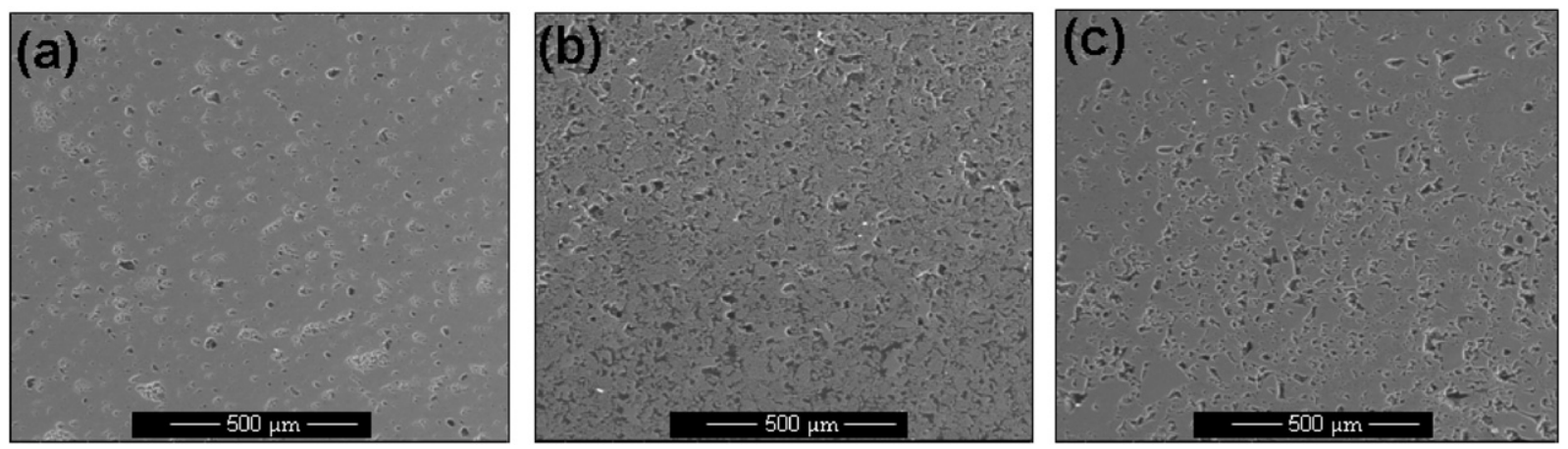

Fig. 1. ESEM micrographs of the cross sections of BGCaM80 (a), BGCaM30 (b) composites and of $45 \mathrm{~S} 5$ (c) sintered bodies.

Differences among groups were established with $t$-test analysis by a two population comparison. Statistical significance was considered at a probability $p<0.05$.

\section{Results and discussion}

\subsection{Microstructural and mechanical characterization; assessment of in vitro bioactivity}

Fig. 1 summarizes the different microstructures of the cross sections of the BGCaM80, BGCaM30 composites and 45S5 sintered bodies by means of ESEM micrographs. Although all the samples are consolidated, however the BGCaM30 ones are characterized by a higher residual porosity with respect to the BGCaM80 ones due to their lower glass content. The addition of glass, in fact, can significantly enhance the sinterability of HA $[43,44]$ and hence it is reasonable that the BGCaM80 samples look particularly well densified, due to their high content of glass ( $80 \mathrm{wt} . \%$ ). The good densification of the composites greatly depends on the retarded crystallization of the BG_Ca/Mix glass compared to the 4555 Bioglass ${ }^{\circledR}$, which in turn derives from the limited amount of network modifiers and the high content of calcium oxide in the glass composition $[23,24]$. In fact, previous contributions have proved that the BG_Ca/Mix glass crystallizes at high temperature, up to about $880^{\circ} \mathrm{C}[23,24]$. The 4555 Bioglass ${ }^{\circledR}$, instead, crystallizes at about $610{ }^{\circ} \mathrm{C}$ after a glass-to-glass separation at about $570{ }^{\circ} \mathrm{C}$, and its precocious crystallization greatly retards its sintering process $[17,18$, 45]. For these reasons, temperatures between $1000{ }^{\circ} \mathrm{C}$ and $1100{ }^{\circ} \mathrm{C}$ are usually employed to densify $45 \mathrm{~S} 5$ powders [46]; so, it is not surprising that the $45 \mathrm{~S} 5$ samples in Fig. 1(c), in spite of the long ( $3 \mathrm{~h}$ ) treatment at $1050{ }^{\circ} \mathrm{C}$, still retain some residual porosity. According to the available literature, even higher temperatures (between $1200^{\circ} \mathrm{C}$ and $1300^{\circ} \mathrm{C}$ ) are required to sinter $\mathrm{HA} / 45 \mathrm{~S} 5$ composites, which results in several drawbacks, such as HA decomposition with the formation of $\mathrm{CaO}$ or tricalcium phosphate (TCP) [15] and the development of undesired phases from the reaction between glass and HA [16].

Although the BGCaM80 composites have been treated at a temperature $\left(\mathrm{T}=830^{\circ} \mathrm{C}\right)$ which is lower than the BG_Ca/Mix crystallization temperature $\left(\mathrm{T}=880^{\circ} \mathrm{C}\right)$ defined by means of Differential Thermal Analysis [20], the glass in the composites is expected to partly crystallize with the formation of wollastonite $\left(\mathrm{CaSiO}_{3}\right)$ due to the $3 \mathrm{~h}$ of isothermal step performed during sintering. This fact has been previously observed [34] for BG_Ca/Mix-HA composites with a different glass content ( $70 \mathrm{wt} . \%$ instead of $80 \mathrm{wt} . \%)$ treated at a lower temperature $\left(\mathrm{T}=818^{\circ} \mathrm{C}\right)$ for $3 \mathrm{~h}$. As expected, the XRD (see Fig. 2 ) indeed showed the partial devitrification of the glassy phase in both BGCaM80 and BGCaM30 composites, with the development of wollastonite and pseudowollastonite $\left(\mathrm{Ca}_{3}\left(\mathrm{SiO}_{3}\right)_{3}\right)$, respectively. In the XRD spectra, various peaks of the crystalline phases overlap, therefore the univocal attribution of the single peak is difficult. Instead, if the $45 \mathrm{~S} 5$ samples are considered, the devitrification of $45 \mathrm{~S} 5$
Bioglass ${ }^{\circledR}$ gives rise to the formation of the $\mathrm{Na}_{2} \mathrm{CaSi}_{2} \mathrm{O}_{6}$ crystalline phase, as widely reported in the literature (data omitted for the sake of brevity; see, for example $[47,48]$ ).

The results of the mechanical characterization are listed in Table 1. Unfortunately, it was not possible to obtain reliable results for the BGCaM30 samples, probably due to their residual porosity. In fact, the samples are densified, but they are still porous as presented in Fig. 1(b) and the depth-sensing indentation technique is very sensitive to local defects, such as pores. The residual porosity also affects the mechanical properties of the 45S5 sintered samples, whose values of the elastic modulus and, most of all, of the hardness are lower than those usually declared in the literature for pure bulk (melt-derived) 45S5 glass. Thomson and Hench, for example, report a Vickers hardness of $4.58 \pm 9.4 \mathrm{GPa}$ and a Young's modulus of $35 \mathrm{GPa}$ for Bioglass ${ }^{\circledR}$ (45S5) [49]. However the comparison should be considered with caution, since the behaviour of a sintered glass is different from that of the melt-derived counterpart and its properties are greatly influenced by the processing and sintering conditions, such as the thermal schedule to consolidate it, the grain size distribution of the starting powders, etc. Moreover, the obtained values of the mechanical properties can be also affected by the specific measurement technique applied [50]. The properties of the BGCaM80 are sensibly higher than those of the 45S5 reference and this is due to two concomitant factors. First of all, the BG_Ca/Mix glass, on account of its peculiar thermal behaviour, effectively favours the sintering process of the composite, thus reducing the residual porosity. Moreover the presence of (crystalline) HA, which is mechanically stronger than the glass, results in an improvement of the behaviour of the composite $[16,34]$.

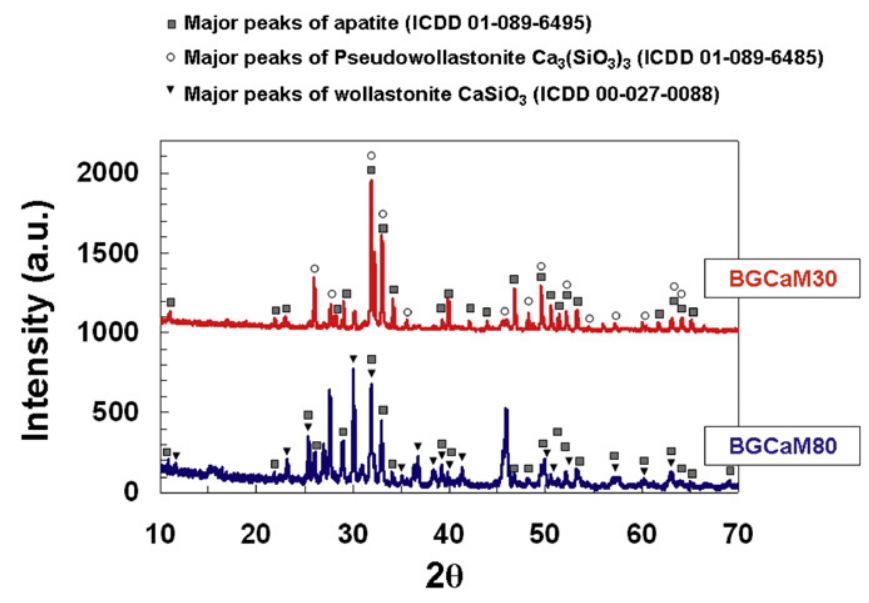

Fig. 2. XRD spectra of BGCaM80 and BGCaM30 samples. 
Table 1

Mechanical properties (Vickers hardness and elastic modulus) of the composites and of the $45 \mathrm{~S} 5$ counterpart. Values expressed as average \pm standard deviation.

\begin{tabular}{lll}
\hline Sample & HV [Vickers] & E [GPa] \\
\hline BGCaM30 & - & - \\
BGCaM80 & $368.1 \pm 83.3$ & $71.5 \pm 8.8$ \\
$45 S 5$ & $61.2 \pm 15.4$ & $30.4 \pm 6.9$ \\
\hline
\end{tabular}

The mechanical performance of the BGCaM80 samples is slightly better than that of the BG_Ca/Mix-HA composites discussed in Ref. [34] (glass content: $70 \mathrm{wt} . \%$; firing temperature: $818{ }^{\circ} \mathrm{C}$ ), which achieved a Vickers hardness of $\sim 299 \mathrm{HV}$ and an elastic modulus of $\sim 42 \mathrm{GPa}$. From this point of view, it is possible to infer an increase in the mechanical properties of the composites with increasing glass contents, probably due to a stronger compaction during sintering. However, a direct comparison between the two sets of samples is not straightforward, since different heat treatments were required to sinter them. As a general consideration, it is not possible to state in absolute terms what value of glass content is most beneficial, since the key issue is the specific use the implant is designed for. In fact, composites with a relatively low glass content are probably less reactive in vivo, since the reaction rate of HA is usually lower than that of bioactive glasses. Moreover they are more porous, which is expected to enhance the cell adhesion and infiltration, but also to reduce the mechanical properties, as discussed before. For this reason, such materials could be employed to realize implants for localized and controlled drug release. On the contrary, higher glass amounts should be preferred for load bearing applications, especially if a fast response in terms of bioactivity is required.

Before performing the cell culture experiments, the apatite-forming ability of BGCaM80 and BGCaM30 samples was preliminary investigated in vitro. The surface of the BGCaM30 samples after exposure to SBF for different soaking times is shown in Fig. 3 by means of ESEM

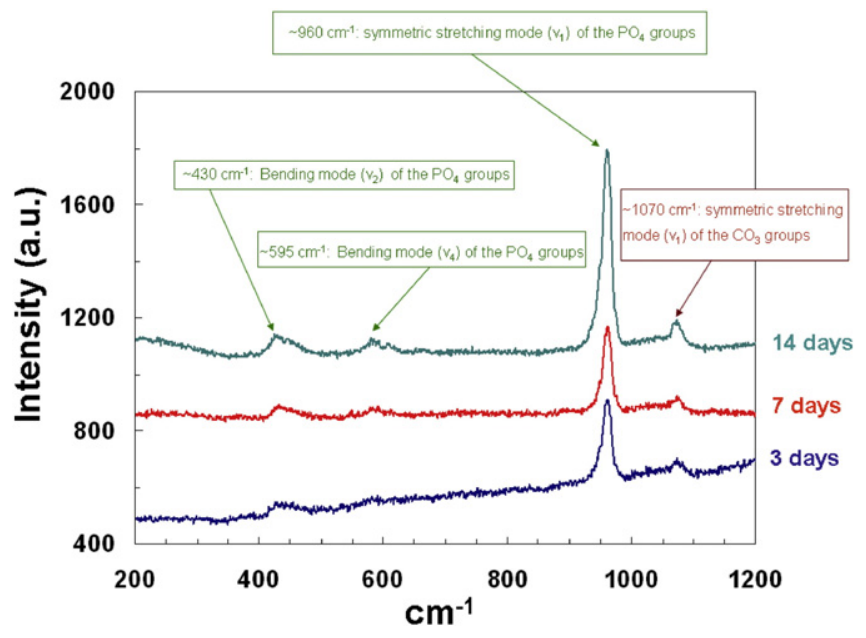

Fig. 4. Raman spectrum acquired on the hydroxyapatite precipitates covering the BGCaM30 sample after 3, 7 and 14 days in SBF.

micrographs. It is possible to observe the formation of globular white precipitates, with the typical morphology of hydroxy-carbonate apatite (HCA). The precipitation of HCA is promoted by the glass, which mainly preserved its amorphous nature and related bioactivity. Moreover, the partial crystallization of the glass to wollastonite (or pseudowollastonite) is not detrimental to the apatite-forming ability: in this sense, the in vitro formation of a HCA layer on the surface of sintered wollastonite is reported in the literature [51,52]. The HCA precipitation on the samples was clearly detectable already after 3 days (Fig. 3(a)), and HCA deposits progressively spread on the surface with increasing soaking time. Fig. 3(b) and (d) show the HCA formed on BGCaM30 after 7 days in SBF and a high magnification micrograph of the HCA after 14 days,

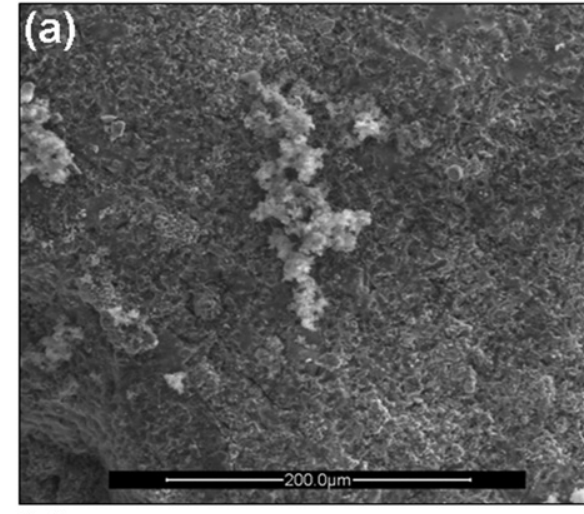

(c)

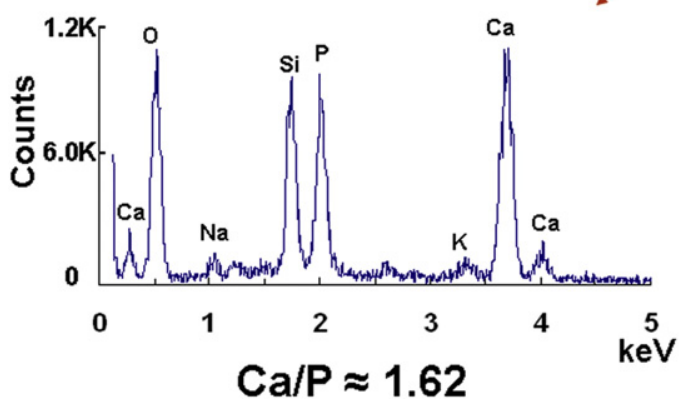

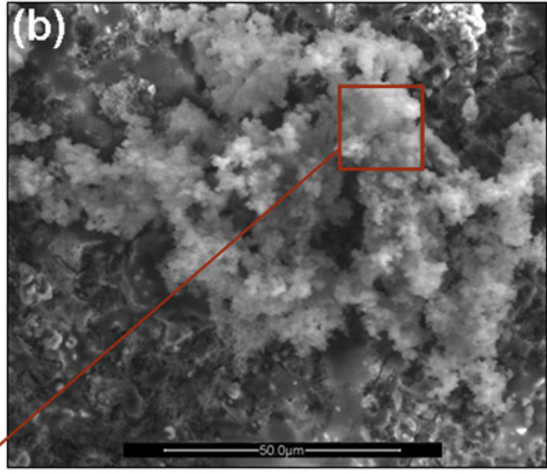

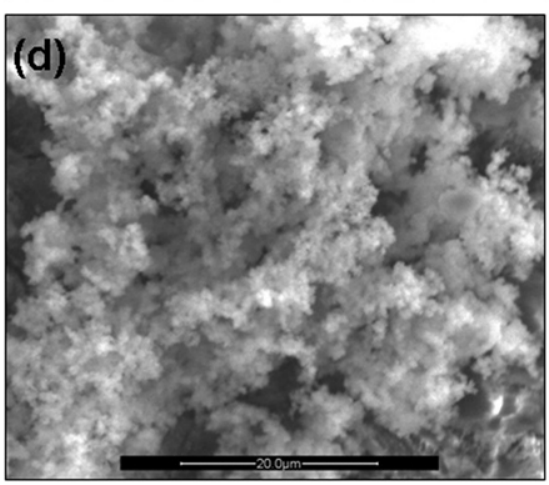

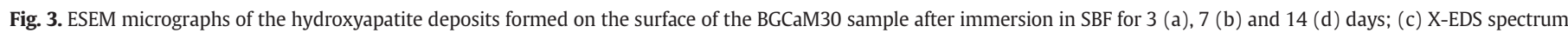
acquired on the area is reported in (b). 


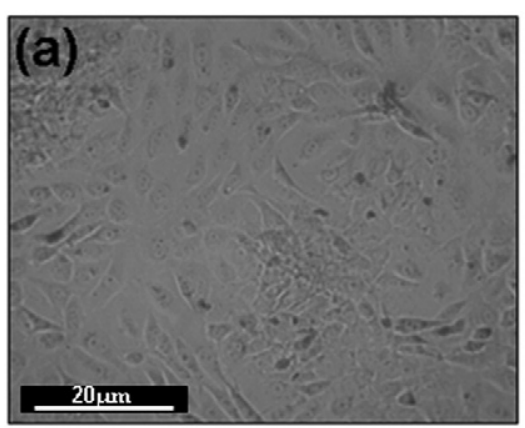

BGCaM80

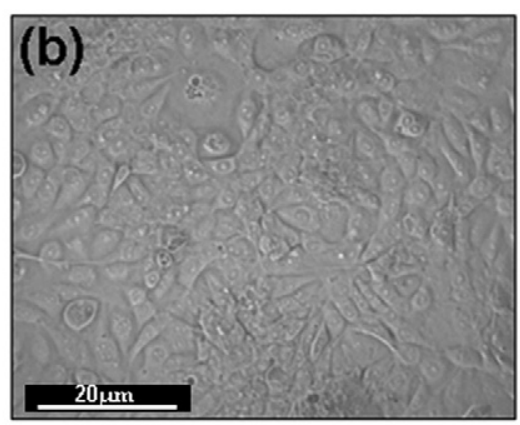

BGCaM30

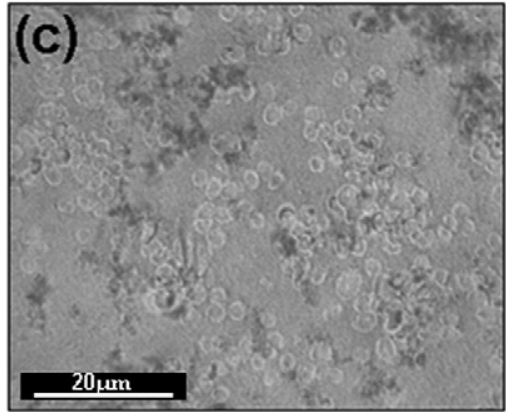

Bioglass $^{\circledR} 45 \mathrm{S5}$

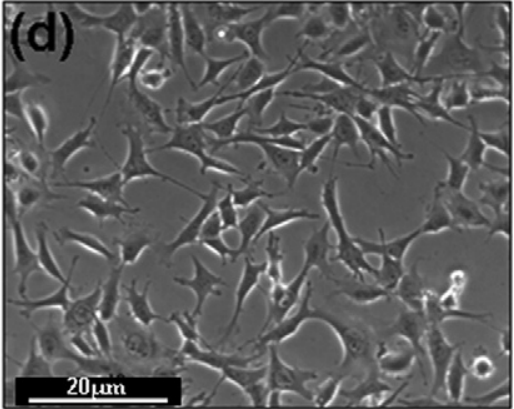

CTRL-

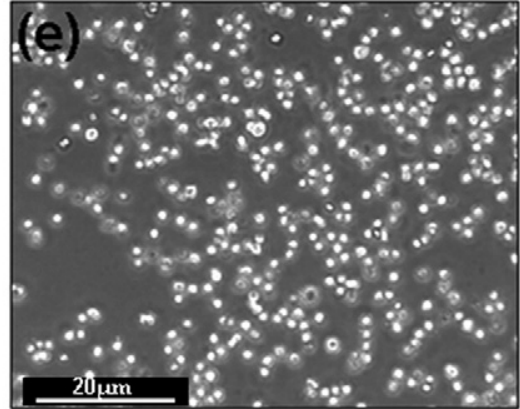

CTRL+

Fig. 5. Morphological evaluation of BALB/3T3 cells after $24 \mathrm{~h}$ direct contact with the samples using optical microscopy $140 \times$ magnification (Nikon TMF, Japan).

respectively. The chemical composition of the globular deposits, evaluated by means of X-EDS (Fig. 3(c)), reports a Ca/P ratio $(\sim 1.62)$ very close to that of stoichiometric HA ( 1.67 [13]), apart from local fluctuations. The identification of the precipitates as HCA was further confirmed by Raman spectroscopy (see Fig. 4). In fact, besides the peak at $\sim 960 \mathrm{~cm}^{-1}$, which is ascribable to the totally symmetric stretching mode $\left(v_{1}\right)$ of the $\left(\mathrm{PO}_{4}\right)^{3-}$ group, it is possible to observe two peaks at $\sim 600 \mathrm{~cm}^{-1}$ and $\sim 430 \mathrm{~cm}^{-1}$, which are associated to the

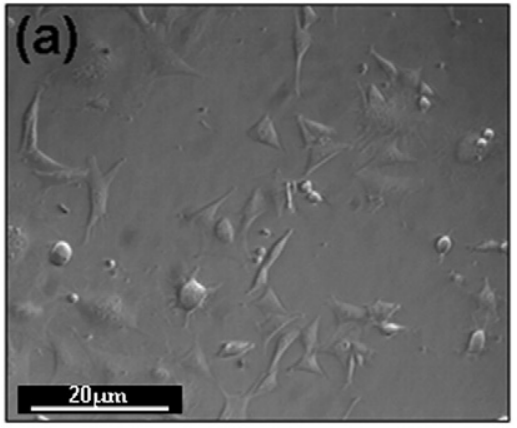

BGCaM80

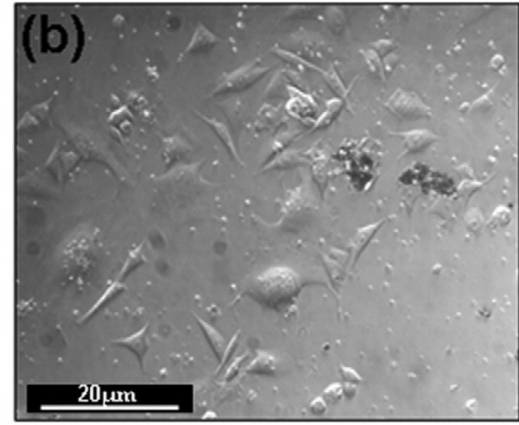

BGCaM30

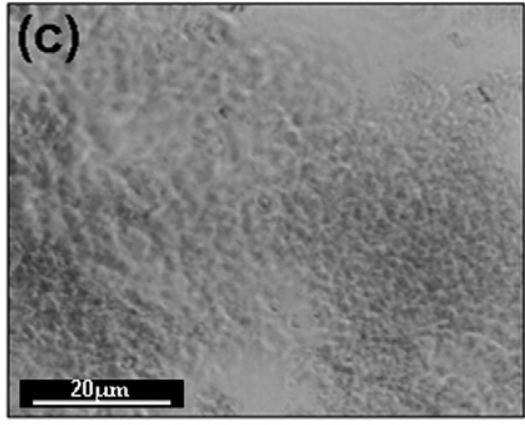

Bioglass $^{\circledast 45 S 5}$

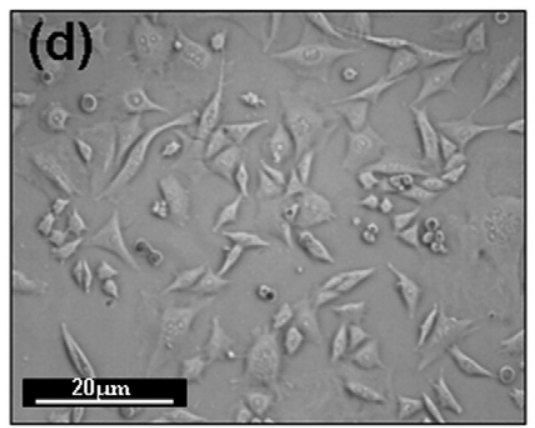

CTRL-

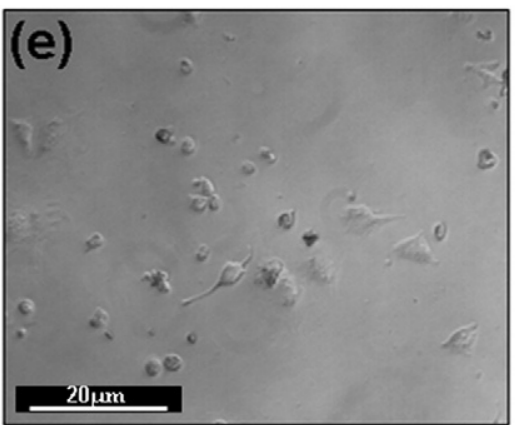

CTRL+

Fig. 6. Morphological evaluation of MLO-Y4 cells after $24 \mathrm{~h}$ direct contact with the samples using optical microscopy $140 \times$ magnification (Nikon TMF, Japan). 

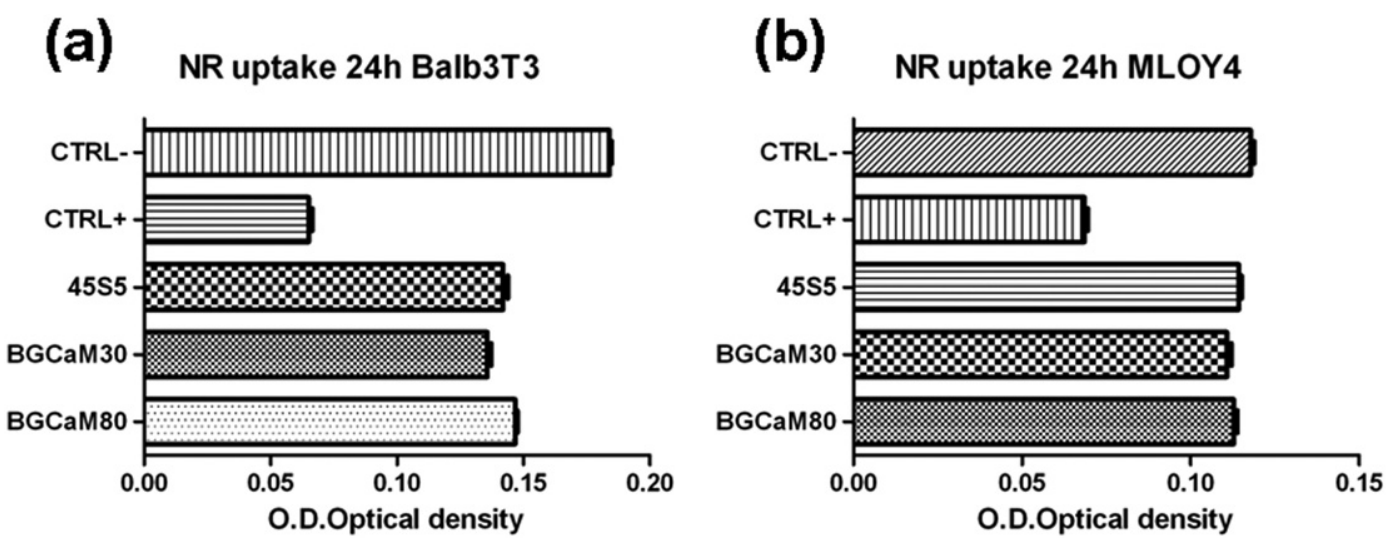

Fig. 7. NR uptake after $24 \mathrm{~h}$ in the different samples.

$v_{4}$ and to the $v_{2}$ bending modes of the $\left(\mathrm{PO}_{4}\right)^{3-}$ group, respectively [53, 54]. Moreover, it is possible to observe a peak at $\sim 1070 \mathrm{~cm}^{-1}$, which is ascribable to the symmetric stretching mode $\left(v_{1}\right)$ of the $\mathrm{CO}_{3}$ groups [55]. Similar results have been obtained for BGCaM80 samples (data omitted for the sake of brevity), while the investigation of the $45 \mathrm{~S} 5$ bioactivity has been reported in previous works [35,47].

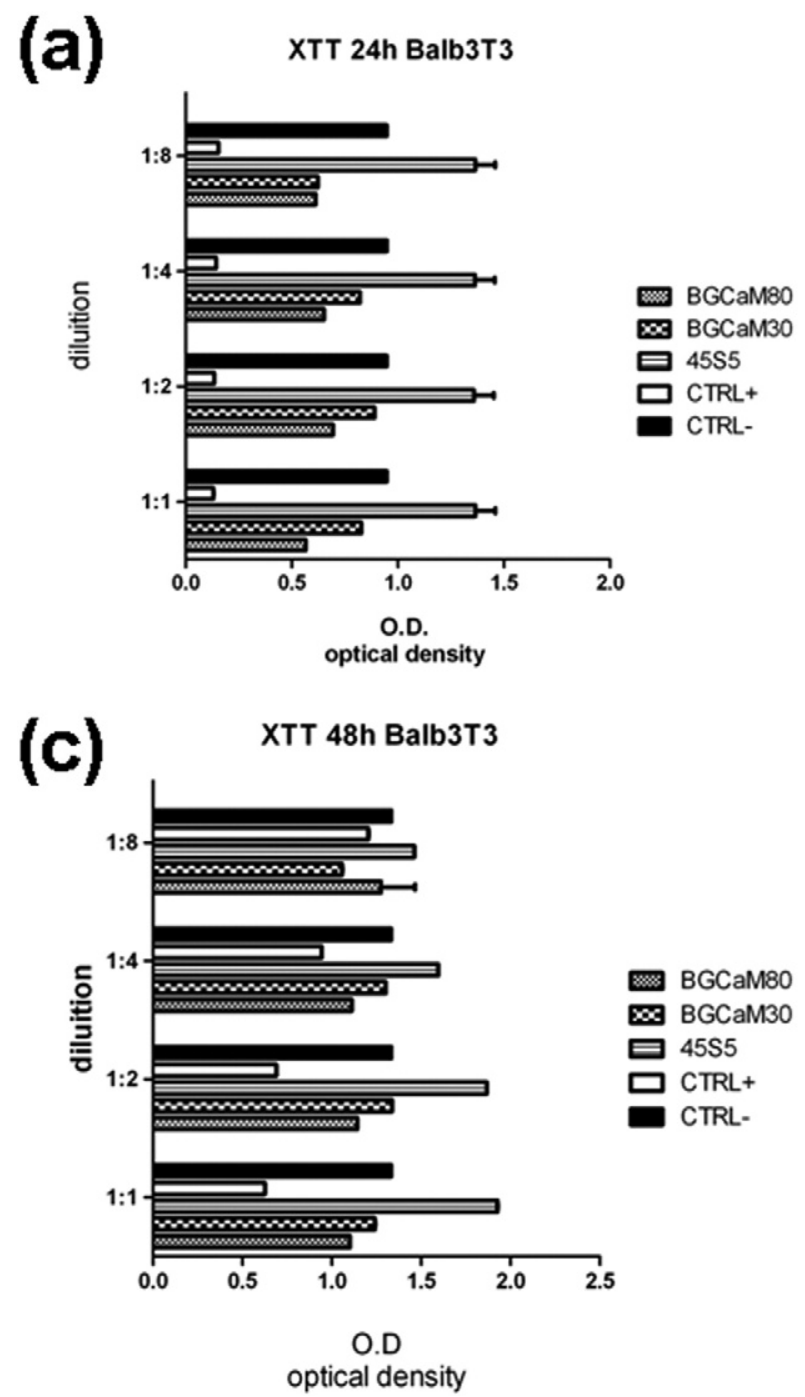

\subsection{Biocompatibility tests}

Although SBF tests are a simple and cheap tool to preliminary investigate the bioactivity of a biomaterial, however the results should be interpreted carefully. In recent years the reliability of such tests has been often criticized and several researchers pointed out that the

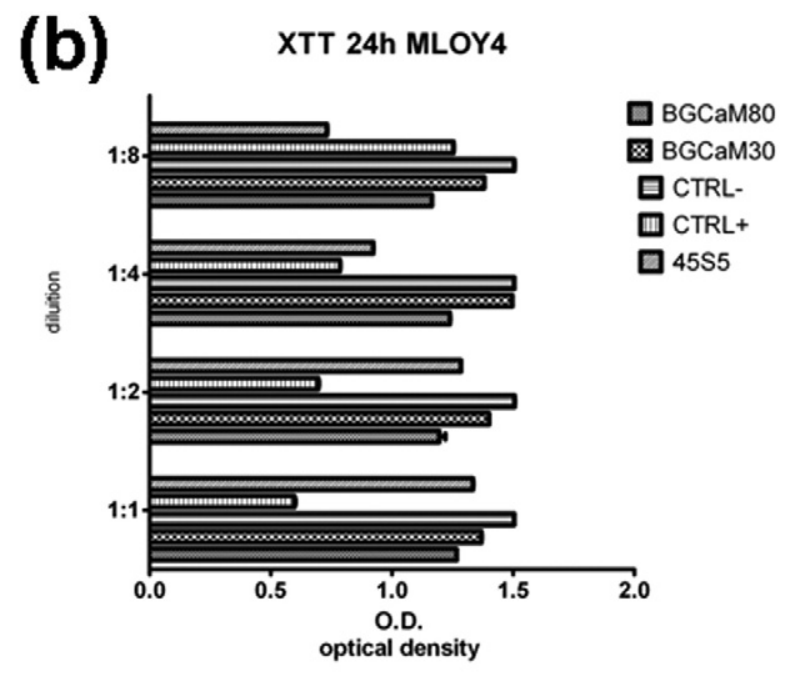

(d)

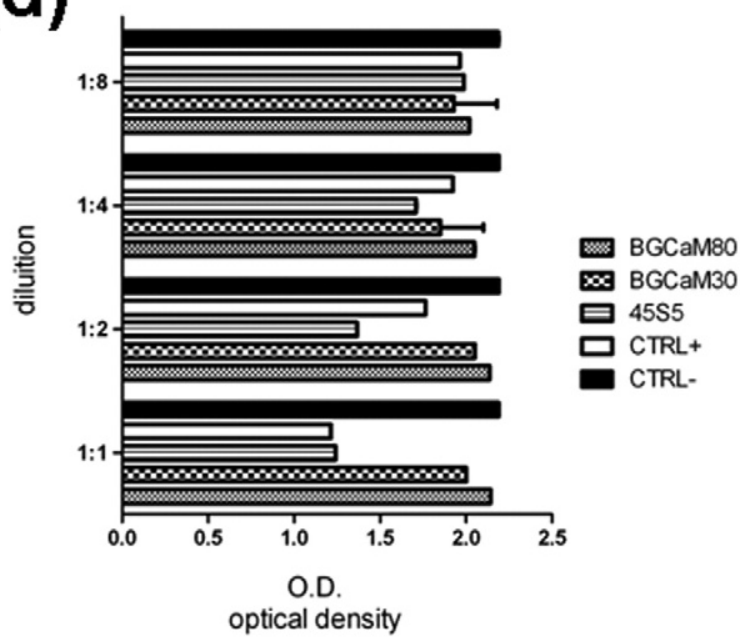


apatite forming ability in SBF, i.e. the formation of an apatitic layer on the material, cannot be assumed as a predictor of bioactivity also in vivo $[56,57]$. In particular, SBF only contains inorganic ions with concentrations similar to those of human plasma, therefore the assumption to mimic the complex and dynamic physiological environment by means of such solution, which doesn't contain many key factors involved in osteogenesis, such as proteins or specific trace elements [58, 59], looks overly simplistic. Moreover, bioactivity testing with SBF may lead both to false positive and false negative results. For example, $\beta$ TCP does not always induce the precipitation of apatite in SBF despite its extensive bone-bonding ability in vivo [60], while other materials form apatite in vitro but do not bond to the bone once implanted in the body [61-63]. For these reasons, the real significance of the apatite-formation ability in SBF is not fully understood and the investigation of the bioactivity in SBF for a given material may not be exhaustive in order to predict its bone-bonding ability in vivo. In this sense, cytotoxicity tests based on in vitro cell culture are fundamental to ascertain the biocompatibility of new materials intended for biomedical applications, since they provide a measure of cell death caused by biomaterials or their degradation products. In vitro cell culture assays are rapid and standardized, and they have the advantage of relatively well-controlled variables and of affordable costs. They are therefore widely employed as a predictor of potential toxic effects in whole animals, thus reducing the number of animals necessary to complete the investigation $[64,65]$. In particular, such tests are essential to develop new biomedical materials to be used as scaffolds $[46,47,66]$, which modulate cell viability, differentiation and proliferation.

In this study, the cytotoxicity of the produced bioceramic composites was investigated using direct and indirect contact approaches. BALB/ 3T3 mouse fibroblast cells and MLO-Y4 murine osteocyte-like cells were employed. Nowadays BALB/3T3 fibroblasts, i.e. the main cellular component of dense connective tissues, are commonly used for this type of research because they conform to the International Standards Organization (ISO) requirements for evaluating the cytotoxicity of biomaterials and medical devices [38,39,59]. On the other hand, since the composites proposed in the present contribution have been designed to be employed in bone tissue engineering and repair, they were further tested with respect to MLO-Y4, i.e. an osteocite-like immortalized cell line isolated from murine long bones, whose properties are very similar to those of primary osteocytes [67-71]. In recent years osteocytes have been a major focus in the bone field research, since they represent more than $95 \%$ of the cellular component of mature adult bone [72,73].
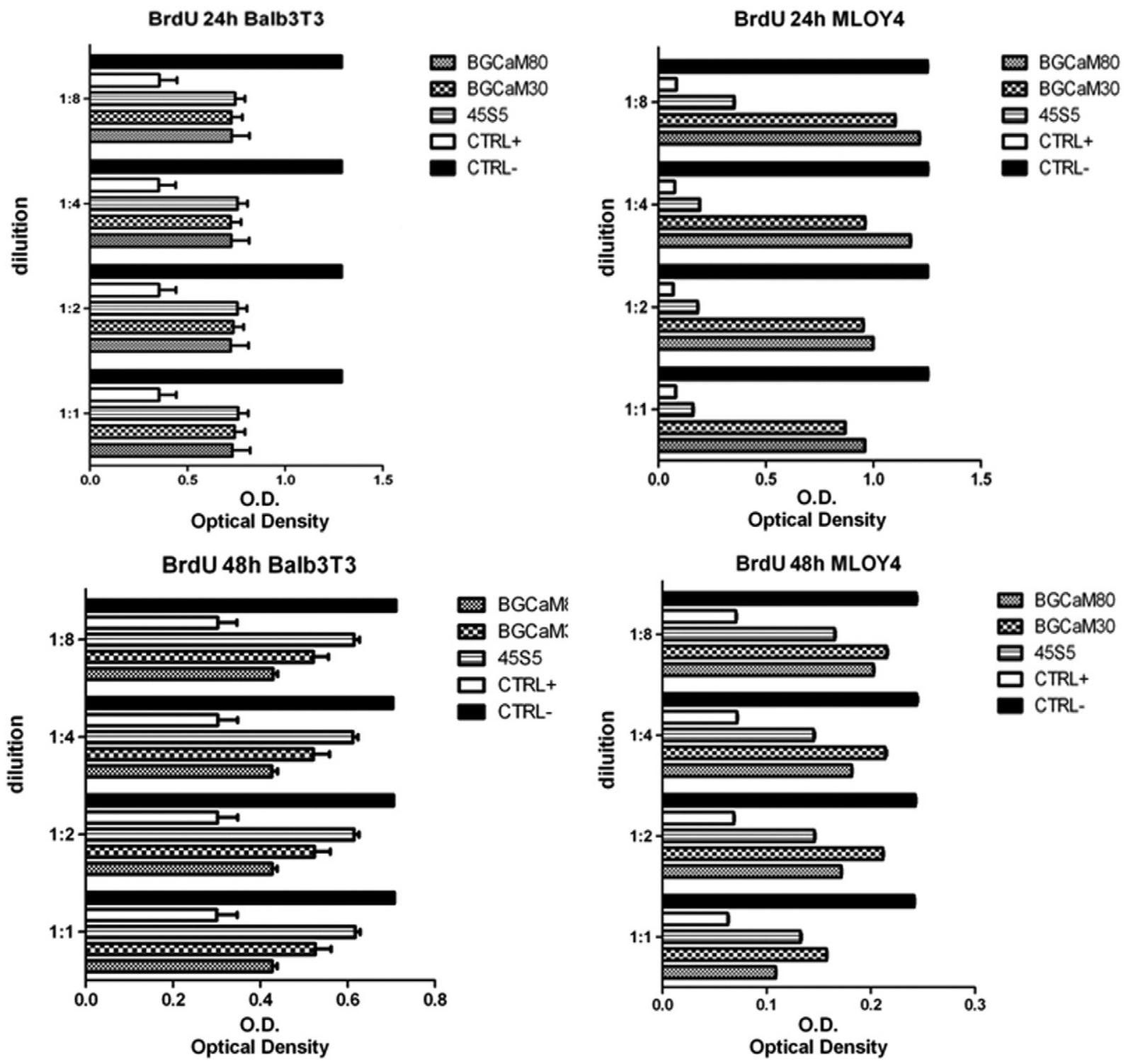

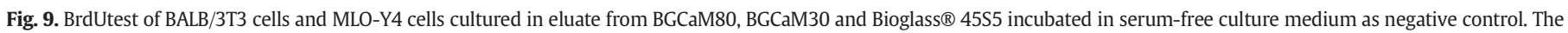
results after $48 \mathrm{~h}$ contact are quite similar to those of the control. 
The behaviour of the BALB/3T3 cells and that of the MLO-Y4 cells after $24 \mathrm{~h}$ direct contact with the composites has been investigated using optical microscopy, as shown in Figs. 5 and 6, respectively. Even if the HA content is different in the two composites, no relevant effects could be detected on the behaviour of the cells. In fact, both types of cells grew very well on both composites and they developed a morphology analogous to that of the corresponding cells grown on the CTRL-. No significant morphological cellular changes, including lysis, rounding, etc. was observed. It is interesting to note that the morphological evaluation reveals a degradation of the $45 \mathrm{~S} 5$ sample after only $24 \mathrm{~h}$ contact. The optical microscope investigation of the cells after indirect contact tests led to analogous conclusions, therefore these results have been omitted for the sake of brevity.

These considerations are confirmed by the results of the viability test with NR uptake, reported in Fig. 7. This test is based on the ability of viable cells to incorporate and store within lysosomes the supravital dye neutral red [74]. Alterations of the cell surface or the lysosomal membrane due to the action of xenobiotics result in a decreased uptake and binding of NR, therefore it is possible to distinguish between viable, damaged or dead cells. The cell cultures and the NR uptake are examined after $24 \mathrm{~h}$ (= one cell cycle) of chemical exposure to the material, and the number of cells is compared to that observed in control cultures, in order to calculate the percentage of inhibition of growth in the cell population [75]. The NR assay has been successfully used to study the toxic effects of chemicals on a variety of cell lines from diverse origin [76-78]. The NR uptake after $24 \mathrm{~h}$ of direct contact to BGCaM80, BGCaM30 and 45S5 samples is similar to CRTL - (Fig. 7), therefore no significant decrease in lysosomal activity imputable to cytotoxic effects can be observed.

Quantitative measurements of cell viability were also performed by means of XTT colorimetric assay, which has been exploited in recent years in order to evaluate the mechanisms of both cell damage and activation [79-81]. Microculture tetrazolium assays - such as XTT are based on the bioreduction of a tetrazolium salt to a coloured formazan by the metabolic activity of viable cells. XTT has the advantage to form soluble formazans, therefore the error-prone solubilization step required in similar assays such as MTT can be omitted [82]. The XTT results reported in Fig. 8 show that BGCaM30 and BGCaM80 samples do not affect negatively the vitality of the cells, which is similar for both fibroblasts and osteocytes.

Finally, the proliferation of cells cultured in eluate from BGCaM80, BGCaM30 and Bioglass ${ }^{\circledR} 45 \mathrm{~S} 5$ was investigated by means of Bromodeoxyuridine (BrdU) assay. Such tests have long been used to detect DNA synthesis in vitro and in vivo, i.e. to investigate the proliferation of cells of interest, since BrdU competes with thymidine and it is incorporated into the DNA, thus acting as a marker which can be tracked and detected by immunohistochemistry [83-86]. According to the BrdU test results reported in Fig. 9, BGCaM30 and BGCaM80 composites do not affect negatively the cells. The same result holds both for fibroblasts and for osteocytes. It is possible to observe that the Bioglass ${ }^{\circledR} 45 \mathrm{~S} 5$ sintered samples stimulate cell proliferation; this fact has been previously discussed by several authors in the literature (see, for example, $[25,87]$ ).

\section{Conclusions}

Bioactive glass/apatite composites with different apatite amounts ( 80 wt.\%; 30 wt.\%) were produced and discussed. 4555 Bioglass $®$ reference samples were also produced by sintering commercial $45 \mathrm{~S} 5$ Bioglass ${ }^{\circledR}$ powders. The use of a recently developed glass composition, namely BG_Ca/Mix, which is characterized by a higher thermal stability with respect to Bioglass $® 45 S 5$, allowed one to sinter the composites at a relatively low temperature with positive effects in terms of in vitro bioactivity. The mechanical properties of BGCaM80, i.e. the set of composites with the higher glass content, are sensibly higher than those of the $45 \mathrm{~S} 5$ reference and this fact can be ascribed to (1) the presence of apatite, which is mechanically stronger than the 45S5 glass, and
(2) the peculiar thermal behaviour of the BG_Ca/Mix glass, which is able to favour the sintering process of the composites. Finally, the results of the cytotoxicity tests performed with murine fibroblasts and osteocites allow one to look with optimism to the produced composites, since both the samples themselves and the samples' extracts do not induce any negative effects in cell viability and do not cause inhibition in cell growth. The good in vitro response of the produced samples open the possibility for future, extended studies on their biological behaviour in vivo as scaffolding materials.

\section{References}

[1] M. Vallet-Regí, Ceramics for medical applications, J. Chem. Soc. Dalton Trans. (2001) 97-108.

[2] A. Beswick, A.W. Blom, Bone graft substitutes in hip revision surgery: a comprehensive overview, Injury 42 (2011) S40-S46.

[3] I. Denry, J.A. Holloway, Ceramics for dental applications: a review, Materials 3 (2010) 351-368.

[4] T. Albrektsson, C. Johansson, Osteoinduction, osteoconduction and osseointegration, Eur. Spine J. 10 (2001) S96-S101.

[5] W. Suchanek, M. Yoshimura, Processing and properties of hydroxyapatite based biomaterials for use as hard tissue replacement implants, J. Mater. Res. 13 (1998) 94-117.

[6] L.L. Hench, Bioceramics: from concept to clinic, J. Am. Ceram. Soc. 74 (1991) 1487-1510.

[7] N. Stiegler, D. Bellucci, G. Bolelli, V. Cannillo, R. Gadow, A. Killinger, L. Lusvarghi, A Sola, High Velocity Suspension Flame Sprayed (HVSFS) hydroxyapatite coatings for biomedical applications, J. Therm. Spray Technol. 21 (2012) 275-287.

[8] G. Bolelli, D. Bellucci, V. Cannillo, L. Lusvarghi, A. Sola, N. Stiegler, P. Müller, A. Killinger, R. Gadow, L. Altomare, L. De Nardo, Suspension thermal spraying of hydroxyapatite: microstructure and in vitro behaviour, Mater. Sci. Eng. C 34 (2014) 287-303.

[9] A. Afonso, J.D. Santos, M. Vasconcelos, R. Branco, J. Cavalheiro, Granules of osteoapatite and glass-reinforced hydroxyapatite implanted in rabbit tibiae, J. Mater. Sci. Mater. Med. 7 (1996) 507-510.

[10] K. So, S. Fujibayashi, M. Neo, Y. Anan, T. Ogawa, T. Kokubo, T. Nakamura, Accelerated degradation and improved bone-bonding ability of hydroxyapatite ceramics by the addition of glass, Biomaterials 27 (2006) 4738-4744.

[11] G. Jell, M.M. Stevens, Gene activation by bioactive glasses, J. Mater. Sci. Mater. Med 17 (2006) 997-1002.

[12] I.D. Xynos, A.J. Edgar, L.D.K. Buttery, L.L. Hench, J.M. Polak, Gene-expression profiling of human osteoblasts following treatment with the ionic products of Bioglass ${ }^{\circledR} 45 \mathrm{~S} 5$ dissolution, J. Biomed. Mater. Res. 55 (2001) 151-157.

[13] G. Göller, H. Demirkiran, F.N. Oktar, E. Demirkesen, Processing and characterization of bioglass reinforced hydroxyapatite composites, Ceram. Int. 29 (2003) 721-724.

[14] F.N. Oktar, G. Göller, Sintering effects on mechanical properties of glass-reinforced hydroxyapatite composites, Ceram. Int. 28 (2002) 617-621.

[15] W. Suchanek, M. Yashima, M. Kakihana, M. Yoshimura, Hydroxyapatite ceramics with selected sintering additives, Biomaterials 18 (1997) 923-933.

[16] D.C. Tancred, A.J. Carr, B.A.O. McCormack, The sintering and mechanical behaviour of hydroxyapatite with Bioglass additions, J. Mater. Sci. Mater. Med. 12 (2001) 81-93.

[17] D.C. Clupper, L.L. Hench, Crystallization kinetics of tape cast bioactive glass, J. NonCryst. Solids 318 (2003) 43-48.

[18] D. Bellucci, V. Cannillo, A. Sola, An overview of the effects of thermal processing on bioactive glasses, Sci. Sinter. 42 (2010) 307-320.

[19] O.P. Filho, G.P. La Torre, L.L. Hench, Effect of crystallization on apatite-layer formation of bioactive glass 45S5, J. Biomed. Mater. Res. 30 (1996) 509-514.

[20] D. Bellucci, V. Cannillo, A. Sola, A new highly bioactive composite for scaffolds applications: a feasibility study, Materials 4 (2011) 339-354.

[21] D. Bellucci, A. Sola, M. Gazzarri, F. Chiellini, V. Cannillo, A new hydroxyapatite-based biocomposite for bone replacement, Mater. Sci. Eng. C 33 (2013) 1091-1101.

[22] A. Sola, D. Bellucci, M.G. Raucci, S. Zeppetelli, L. Ambrosio, V. Cannillo, Heat Treatment of $\mathrm{Na}_{2} \mathrm{O}-\mathrm{CaO}-\mathrm{P}_{2} \mathrm{O}_{5}-\mathrm{SiO}_{2}$ bioactive glasses: densification processes and postsintering bioactivity, J. Biomed. Mater. Res. A 100A (2012) 305-322.

[23] D. Bellucci, A. Sola, V. Cannillo, Low temperature sintering of innovative bioactive glasses, J. Am. Ceram. Soc. 95 (2012) 1313-1319.

[24] D. Bellucci, V. Cannillo, A. Sola, Calcium and potassium addition to facilitate the sintering of bioactive glasses, Mater. Lett. 65 (2011) 1825-1827.

[25] A. Hoppe, N.S. Güldal, A.R. Boccaccini, A review of the biological response to ionic dissolution products from bioactive glasses and glass-ceramics, Biomaterials 32 (2011) 2757-2774.

[26] S.V. Dorozhkin, M. Epple, Biological and medical significance of calcium phosphates, Angew Chem. Int. Ed Engl. 41 (41) (2002) 3130-3146.

[27] M. Brink, T. Turunen, R.P. Happonen, A. Yli-Urpo, Compositional dependence of bioactivity of glasses in the system $\mathrm{Na}_{2} \mathrm{O}-\mathrm{K}_{2} \mathrm{O}-\mathrm{MgO}-\mathrm{CaO}-\mathrm{B}_{2} \mathrm{O}_{3}-\mathrm{P}_{2} \mathrm{O}_{5}-\mathrm{SiO}_{2}$, J. Biomed. Mater. Res. 37 (1997) 114-121.

[28] C. Vitale-Brovarone, E. Verné, L. Robiglio, G. Martinasso, R.A. Canuto, G. Murzio, Biocompatible glass-ceramic materials for bone substituition, J. Mater. Sci. Mater. Med. 19 (2008) 471-478.

[29] C. Vitale-Brovarone, F. Baino, M. Miola, R. Mortera, B. Onida, E. Verné, Glass-ceramic scaffolds containing silica mesophases for bone grafting and drug delivery, J. Mater Sci. Mater. Med. 20 (2009) 809-820. 
[30] Z.Y. Wu, R.G. Hill, S. Yue, D. Nightingale, P.D. Lee, J.R. Jones, Melt-derived bioactive glass scaffolds produced by a gel-cast foaming technique, Acta Biomater. 7 (2011) 1807-1816.

[31] J.D. Santos, R.L. Reis, F.J. Monteiro, J.C. Knowles, G.W. Hastings, Liquid phase sintering of hydroxyapatite by phosphate and silicate glass additions: structure and properties of the composites, J. Mater. Sci. Mater. Med. 6 (1995) 348-352.

[32] J.D. Santos, P.L. Silva, J.C. Knowles, S. Talal, F.J. Monteiro, Reinforcement of hydroxyapatite by adding $\mathrm{P}_{2} \mathrm{O}_{5}-\mathrm{CaO}$ glasses with $\mathrm{Na}_{2} \mathrm{O}, \mathrm{K}_{2} \mathrm{O}$ and $\mathrm{MgO}$, J. Mater. Sci. Mater. Med. 7 (1996) 187-189.

[33] P. Gentile, D. Bellucci, A. Sola, C. Mattu, V. Cannillo, G. Ciardelli, Composite scaffolds for controlled drug release: Role of the polyurethane nanoparticles on the physical properties and cell behaviour, J. Mech. Behav. Biomed. Mater. 44 (2015) 53-60.

[34] D. Bellucci, A. Sola, V. Cannillo, Bioactive glass-based composites for the production of dense sintered bodies and porous scaffolds, Mater. Sci. Eng. C 33 (2013) $2138-2151$.

[35] D. Bellucci, V. Cannillo, A. Sola, F. Chiellini, M. Gazzarri, C. Migone, Macroporous Bioglass $₫$-derived scaffolds for bone tissue regeneration, Ceram. Int. 37 (2011) 1575-1585.

[36] W.C. Oliver, G.M. Pharr, An improved technique for determining hardness and elastic modulus using load and displacement sensing indentation experiments, J. Mater. Res. 7 (1992) 1564-1583.

[37] T. Kokubo, H. Takadama, How useful is SBF in predicting in vivo bone bioactivity? Biomaterials 27 (2006) 2907-2915.

[38] International Standard 10993-5, Biological evaluation of medical devices - part 5 : tests for cytotoxicity: in vitro methods, 2009.

[39] International Standard 10993-12, Biological evaluation of medical devices - part 12: sample preparation and reference materials, 2007

[40] D.A. Scudiero, R.H. Shoemaker, K.D. Paull, A. Monks, S. Tierney, T.H. Nofziger, M.J. Currens, D. Seniff, M.R. Boyd, Evaluation of a soluble tetrazolium/formazan assay for cell growth and drug sensitivity in culture using human and other tumor cell lines, Cancer Res. 48 (1988) 4827-4833.

[41] T. Mosmann, A rapid colorimetric assay for cellular growth and survival: application to proliferation and cytotoxicity assays, J. Immunol. Methods 65 (1983) 55-63.

[42] G. Ciapetti, D. Granchi, S. Stea, L. Savarino, E. Verri, A. Gori, F. Salvioli, L. Montanaro, Cytotoxicity testing of materials with limited in vivo exposure is affected by the duration of cell-material contact, J. Biomed. Mater. Res. 42 (1998) 485-490.

[43] D.C. Tancred, B.A. McCormack, A.J. Carr, A quantitative study of the sintering and mechanical properties of hydroxyapatite/phosphate glass composites, Biomaterials 19 (1998) 1735-1743.

[44] J.C. Knowles, S. Talal, J.D. Santos, Sintering effects in a glass reinforced hidroxyapatite, Biomaterials 17 (1996) 1437-1442.

[45] A.R. Boccaccini, Q. Chen, L. Lefebvre, L. Gremillard, J. Chevalier, Sintering, crystallisation and biodegradation behaviour of Bioglass-derived glass-ceramics, Faraday Discuss. 136 (2007) 27-44.

[46] Q.Z. Chen, I.D. Thompson, A.R. Boccaccini, 45S5 Bioglass ${ }^{\circledR}$-derived glass-ceramic scaffolds for bone tissue engineering, Biomaterials 27 (2006) 2414-2425.

[47] D. Bellucci, V. Cannillo, F. Chiellini, G. Ciardelli, M. Gazzarri, P. Gentile, A. Sola, Processing and characterization of innovative scaffolds for bone tissue engineering, J. Mater. Sci. Mater. Med. 23 (2012) 1397-1409.

[48] L. Lefebvre, L. Gremillard, J. Chevalier, R. Zenati, D. Bernache-Assolant, Sintering behaviour of $45 S 5$ bioactive glass, Acta Biomater. 4 (2008) 1894-1903.

[49] I.D. Thomson, L.L. Hench, Mechanical properties of bioactive glasses, glass-ceramics and composites, Proc. Inst. Mech. Eng. H 212 (1998) 127-136.

[50] D. Bellucci, A. Sola, V. Cannillo, Bioactive glass $/ \mathrm{ZrO}_{2}$ composites for orthopaedic applications, Biomed. Mater. 9 (2014) 015005.

[51] P. Siriphannon, Y. Kameshima, A. Yasumori, K. Okada, S. Hayashi, Formation of hydroxyapatite on $\mathrm{CaSiO}_{3}$ powders in simulated body fluid, J. Eur. Ceram. Soc. 22 (2002) 511-520

[52] X. Liu, C. Ding, Z. Wang, Apatite formed on the surface of plasma-sprayed wollastonite coating immersed in simulated body fluid, Biomaterials 22 (2001) 2007-2012.

[53] S. Koutsopoulos, Synthesis and characterization of hydroxyapatite crystals: a review study on the analytical methods, J. Biomed. Mater. Res. 62 (2002) 600-612.

[54] D. Bellucci, G. Bolelli, V. Cannillo, A. Cattini, A. Sola, In situ Raman spectroscopic investigation of bioactive glass reactivity: Simulated Body Fluid solution VS TRISbuffered solution, Mater. Charact. 62 (2011) 1021-1028.

[55] A. Awonusi, M.D. Morris, M.M.J. Tecklenburg, Carbonate assignment and calibration in the Raman spectrum of apatite, Calcif. Tissue Int. 81 (2007) 46-52.

[56] M. Bohner, J. Lemaitre, Can bioactivity be tested in vitro with SBF solution? Biomaterials 30 (2009) 2175-2179.

[57] H. Pan, X. Zhao, B.W. Darvell, W.W. Lu, Apatite-formation ability - predictor of "bioactivity"? Acta Biomater. 6 (2010) 4181-4188.

[58] W. Paul, C.P. Sharma, Effect of calcium, zinc and magnesium on the attachment and spreading of osteoblast like cells onto ceramic matrices, J. Mater. Sci. Mater. Med. 18 (2007) 699-703.

[59] E. Bonnelye, A. Chabadel, F. Saltel, P. Jurdic, Dual effect of strontium ranelate: stimulation of osteoblast differentiation and inhibition of osteoclast formation and resorption in vitro, Bone 42 (2008) 129-138.
[60] S. Kotani, Y. Fujita, T. Kitsugi, T. Nakamura, T. Yamamuro, C. Ohtsuki, et al., Bonebonding mechanism of beta-tricalcium phosphate, J. Biomed. Mater. Res. 25 (1991) 1303-1315.

[61] W.R. Walsh, P. Morberg, Y. Yu, J.L. Yang, W. Haggard, P.C. Sheath, et al., Response of a calcium sulfate bone graft substitute in a confined cancellous defect, Clin. Orthop. 406 (2003) 228-236.

[62] F. Theiss, D. Apelt, B. Brand, A. Kutter, K. Zlinszky, M. Bohner, et al., Biocompatibility and resorption of a brushite calcium phosphate cement, Biomaterials 26 (2005) 4383-4394.

[63] K. Ohura, M. Bohner, P. Hardouin, J. Lemaitre, G. Pasquier, B. Flautre, Resorption of, and bone formation from, new beta-tricalcium phosphate-monocalcium phosphate cements: an in vivo study, J. Biomed. Mater. Res. 30 (1996) 193-200.

[64] A.A. Ignatius, L.X. Claes, In vitro biocompatibility of bioresorbable polymers: poly(L, DL-lactide) and poly(L-lactide-co-glycolide), Biomaterials 17 (1996) 831-839.

[65] T.L. Riss, R.A. Moravec, A.L Niles, Cytotoxicity testing: measuring viable cells, dead cells, and detecting mechanism of cell death, Methods Mol. Biol. 740 (2011) 103-114.

[66] D. Bellucci, V. Cannillo, A. Sola, A new potassium-based bioactive glass: sintering behaviour and possible applications for bioceramic scaffolds, Ceram. Int. 37 (2011) 145-157.

[67] S.K. Bhatia, A.B. Yetter, Correlation of visual in vitro cytotoxicity ratings of biomaterials with quantitative in vitro cell viability measurements, Cell Biol. Toxicol. 24 (2008) 315-319.

[68] Y. Kato, J.J. Windle, B.A. Koop, G.R. Mundy, L.F. Bonewald, Establishment of an osteocyte-like cell line. MLO-Y4, J. Bone Miner. Res. 12 (1997) 2014-2023.

[69] L.F. Bonewald, Establishment and characterization of an osteocyte-like cell line, MLO-Y4, J. Bone Miner. Metab. 17 (1999) 61-65.

[70] J. Rosser, L.F. Bonewald, Studying osteocyte function using the cell lines MLO-Y4 and MLO-A5, Methods Mol. Biol. 816 (2012) 67-81.

[71] I. Kalajzic, B.G. Matthews, E. Torreggiani, M.A. Harris, P. Divieti Pajevic, S.E. Harris, In vitro and in vivo approaches to study osteocyte biology, Bone 54 (2013) 296-306.

[72] T.A. Franz-Odendaal, B.K. Hall, P.E. Witten, Buried alive: how osteoblasts become osteocytes, Dev. Dyn. 235 (2006) 176-190.

[73] A.M. Parfitt, Bone forming cells in clinical conditions, in: B.K. Hall (Ed.), Bone: A Treatise, The osteoblast and osteocyte, Telford Press, New Jersey, 1990.

[74] E. Borenfreund, J.A. Puerner, A simple quantitative procedure using monolayer culture for toxicity assays, J. Tissue Cult. Methods 9 (1984) 7-9.

[75] M. Liebsch, H. Spielmann, BALB/c 3T3 cytotoxicity test, in: S. O'Hare, C.K. Atterwill (Eds.), Methods in Molecular Biology, Vol. 43, In Vitro Toxicity Testing Protocols, Humana Press, Totowa, NJ, 1995, pp. 177-187.

[76] G. Fotakis, J.A. Timbrell, In vitro cytotoxicity assays: comparison of LDH, neutral red, MTT and protein assay in hepatoma cell lines following exposure to cadmium chloride, Toxicol. Lett. 160 (2006) 171-177.

[77] R. Fautz, B. Husein, C. Hechenberger, Application of the neutral red assay (NR assay) to monolayer cultures of primary hepatocytes: rapid colorimetric viability determination for the unscheduled DNA synthesis test (UDS), Mutat. Res. 253 (1991) 173-179.

[78] D.C. Morgan, C.K. Mills, L.D. Lefkowitz, S.S. Lefkowitz, An improved colorimetric assay for tumor necrosis factor using WEHI 164 cells cultured on novel microtiter plates, J. Immunol. Methods 145 (1991) 259-262.

[79] M.V. Berridge, P.M. Herst, A.S. Tan, Tetrazolium dyes as tools in cell biology: new insights into their cellular reduction, Biotechnol. Annu. Rev. 11 (2005) 127-152.

[80] J. Hasen, P. Bross, A cellular viability assay to monitor drug toxicity, Methods Mol. Biol. 648 (2010) 303-311.

[81] H. Wang, H. Cheng, F. Wang, D. Wei, X. Wang, An improved 3-(4,5-dimethylthiazol2-yl)-2,5-diphenyl tetrazolium bromide (MTT) reduction assay for evaluating the viability of Escherichia coli cells, J. Microbiol. Methods 82 (2010) 330-333.

[82] C.J. Goodwin, S.J. Holt, S. Downes, N.J. Marshall, Microculture tetrazolium assays: a comparison between two new tetrazolium salts, XTT and MTS, J. Immunol. Methods 179 (1995) 95-103.

[83] G.D. Wilson, Analysis of DNA - measurement of cell kinetics by the bromodeoxyuridine/anti-bromodeoxyuridine method, in: M.G. Ormerod (Ed.), Flow Cytometry. A Practical Approach, 3rd editionOxford University Press, Oxford, 2000, pp. 83-97.

[84] A.C. Begr N.J. McNally, D.C. Shrieve, H. Karcher, A method to measure the duration of DNA synthesis and potential doubling time from a single sample, Cytometry 6 (1985) 620-626.

[85] A.M. Crane, S.K. Bhattacharya, The use of bromodeoxyuridine incorporation assays to assess corneal stem cell proliferation, Methods Mol. Biol. 1014 (2013) 65-70.

[86] B. Rocha, C. Penit, C. Baron, F. Vasseur, N. Dautigny, A.A. Frietas, Accumulation of bromodeoxyuridine labeled cells in central and peripheral organs: minimal estimates of production and turnover rates of mature lymphocytes, Eur. J. Immunol. 20 (1990) 1697-1708.

[87] I.D. Xynos, M.V. Hukkanen, J.J. Batten, L.D. Buttery, L.L. Hench, J.M. Polak, Bioglass 45S5 stimulates osteoblast turnover and enhances bone formation In vitro: implications and applications for bone tissue engineering, Calcif. Tissue Int. 67 (2000) 321-329. 